\title{
Pharmacognostical, physicochemical,
} and high performance thin layer chromatography evaluation of Manjisthadi $k w a t h a$ in the management of psoriasis

\author{
Jayesh Odedra ${ }^{1}$, A. B. Thakar ${ }^{1}$, N. N. Bhatt ${ }^{2}$, C. R. Harisha ${ }^{3}$, V. J. Shukla ${ }^{4}$ \\ ${ }^{I}$ Department of Panchakarma, IPGT \& RA, Gujarat Ayurved University, Jamnagar, Gujarat, India, ${ }^{2}$ Department \\ of Kayachikitsa, IPGT \& RA, Gujarat Ayurved University, Jamnagar, Gujarat, India, ${ }^{3}$ Department of \\ Pharmacognosy and Pharmaceutics, IPGT \& RA, Gujarat Ayurved University, Jamnagar, Gujarat, India, \\ ${ }^{4}$ Department of Pharmaceutics, IPGT \& RA, Gujarat Ayurved University, Jamnagar, Gujarat, India
}

Abstract

Background: Manjisthadi kwatha is mentioned in Ayurvedic classics as a therapeutic formulation to treat Kustha, particularly Ekkustha (psoriasis). There is about 2.5\% of whole world population today who are suffering from psoriasis but management is till unsatisfactory. Manjisthadi kwatha contains manjistha (Rubia cordifolia), Katuki (Picrorhiza kurroa) and Vacha (Acorus calamus), Guduchi (Tinospora cordifolia), Nimbi (Azadirachta indica), Daruharidra (Berberis aristata) and Triphala. All ingredients of Manjisthadi kwatha having Kushthaghna property. The skin diseases are considered in the umbrella of Kushtha. Thus, it is more effective in Psoriasis internally. Materials and Methods: Manjisthadi kwatha powder was evaluated for their pharmacognostic and pharmaceutical analysis. Results: Microscopic characters were found of Manjistha, Nimbi Vacha, and Guduchi Triphla. Results obtained in pharmaceutical parameters of Manjisthadi kwatha powder such as loss on drying $15.19 \%$, ash value $8.48 \%$, and alcohol soluble extract $58.6 \% \mathrm{w} / \mathrm{v}$ are within limit mentioned by Ayurvedic pharmacopoeia of India. High performance thin layer chromatography profile of Manjisthadi kwatha powder showed similarities in number of spots. Conclusion: From the study, data developed can be espoused for laying down the standards for Manjisthadi kwatha.

Key words: High performance thin layer chromatography, Manjisthadi kwatha, pharmaceutical analysis, pharmacognostical

\section{INTRODUCTION}

$M$ anjisthadi comprising of Manjistha, Vacha, Guduchi, Nimba, Katuki, Daruharidra, and Triphla was explained in Shadangdhar samhita for curing of Kustha (Psoriasis). ${ }^{[1]}$ During past decades herbal medicines pointed out in Ayurveda are getting gratitude globally. Maintaining the quality standard of a poly herbal formulation is a challenging task. Available data concerning scientific evaluation of Manjisthadi kwatha is none. Quality control for safety and efficacy of herbal products is of paramount importance. ${ }^{[2,3]}$ With the help of identity, purity, content, and other chemical, physical, or biological properties, or by the manufacturing processes quality can be defined as the status of a drug. The analytical techniques have always been cited to understand the quality of the outcome in Ayurveda. It describes different qualitative parameters to critic genuine plant identification, preparations and having scientific evidence, they are not competent to provide quantitative information. Using the modern techniques, qualitative and quantitative analysis of drugs and instruments of the science is of absolute importance to rationalize their acceptability in modern system of medicine.

Different chromatographic analysis is routinely used and plays an important role in the quality control of

Address for correspondence:

Jayesh Odedra, Department of Panchakarma,

IPGT \& RA, Gujarat Ayurved University, Jamnagar,

Gujarat, India. Phone: +91-9429563141.

E-mail: drjayeshodedra@gmail.com

Received: 09-01-2017

Revised: 24-01-2017

Accepted: 30-01-2017 
Odedra, et al.: Pharmacognostical, physicochemical, evaluation of Manjisthadi kwatha

\begin{tabular}{lllc} 
& \multicolumn{2}{c}{ Table 1: Ingredients of Manjisthadi kwatha } & Puantity \\
\hline Sanskrit name & Latin name & Whole plant & 1 part \\
\hline Manjistha & Rubia cordifolia & Fruit & 1 part \\
Baritaki & Terminalia chebula Retz. & Fruit & 1 part \\
Amalaki & Terminalia bellerica Roxb. & Fruit & 1 part \\
Katuki & Emblica officinalis (Gaertn.) & Root & 1 part \\
Vacha & Picrorhiza kurroa (Royle ex Benth) & Root, hardwood & 1 part \\
Darunisha & Acorus calamus & Fruit, root, hardwood & 1 part \\
Guduchi & Berberis aristata Dc. & Hard wood & 1 part \\
Nimba & Tinospora cordifolia (Thunb.) miers & Fruit, leaf, stem & 1 part \\
\hline
\end{tabular}

R. cordifolia: Rubia cordifolia, T. chebula: Terminalia chebula, E. officinalis: Emblica officinalis, P. kurroa: Picrorhiza kurroa,

A. calamus: Acorus calamus, B. aristata: Berberis aristata, T. cordifolia: Tinospora cordifolia

complex herbal medicines. High performance thin layer chromatography (HPTLC) can provide an electronic image of the chromatographic fingerprint and a densitogram to detect the presence of marker compounds in a plant sample. The advantage of HPTLC in the analytical testing of herbal products is that it provides positive identification as well as visualization of the separated fractions of the sample component and helps in quantitative, qualitative analysis with the same system.

Manjisthadi kwatha is used as drug of choice for Ekkustha (Psoriasis). Hence, current study is anticipated to evaluate Manjisthadi kwatha powder through pharmacognostic, physicochemical and HPTLC analysis.

\section{MATERIALS AND METHODS}

\section{Collection and Preparation of the Drug}

All the row drugs of Manjisthadi kwatha were collected from the pharmacy of IPGT and RA, Jamnagar. The obtained drugs were shade dried, equally amount had taken and made into a coarse powder with help of mechanical grinder. Ingredients of Manjisthadi kwatha are summarized at [Table 1].

\section{Organoleptic Evaluation}

Various parameters of the material such as color, odor, touch, and taste of the Manjisthadi kwatha powder were observed and recorded [Table 2]. ${ }^{[4]}$

\section{Microscopic Evaluation}

Microscopic examination of material powder was carried out with and without staining, by powder microscopy to determine the chemical nature and microphotographs were taken using Carl Zeiss Trinocular microscope. ${ }^{[5]}$

\begin{tabular}{|c|c|}
\hline Organoleptic characters & Results \\
\hline Color & Brownish muddy \\
\hline Odor & Aromatic \\
\hline Taste & Bitter \\
\hline Touch & Rough \\
\hline Appearance & Powder \\
\hline
\end{tabular}

\section{Physicochemical Analysis}

Physicochemical analyses were carried out by following the parameters. Physicochemical analysis such as loss on drying at $110^{\circ} \mathrm{C},{ }^{[6]} \mathrm{pH}$ value, ${ }^{[7]}$ ash value, ${ }^{[8]}$ water soluble extractive, ${ }^{[9]}$ and methanol soluble extractive ${ }^{[10]}$ were recorded.

\section{Preliminary Phytochemical Investigation}

Preliminary phytochemical investigations are carried out by following standard procedure of American Petroleum Institute (API). ${ }^{[1]}$

\section{High Performance Thin Layer Chromatography}

HPTLC was performed as per the guidelines provided by API. ${ }^{[12]}$ A Camag (Switzerland) HPTLC system equipped with a sample applicator Linomat $\mathrm{V}$ was used for application of samples. Methanol extract of kwatha powder was used for spotting. Toluene:ethyl acetate:acetic acid $(7: 2: 1 \mathrm{v} / \mathrm{v})$ was selected as solvent system. Camag TLC scanner 3, Reprostar and wincats 1.3.4 were used for scanning the plates. Camag twin trough glass chamber was used for developing the plates. The developed plate was visualized under visible day light, short ultraviolet (UV) $(254 \mathrm{~nm})$, long UV (366 nm) and after spraying with vanillin-sulfuric acid reagent and again observed in daylight. The reference values were recorded. 


\section{Instrumental Conditions}

Application mode: Camag Linomat V, development chamber: Camag twin trough chamber, plate: Precoated Silica Gel GF 254 plate, chamber saturation: $30 \mathrm{~min}$, development time: $30 \mathrm{~min}$, development distance: $10 \mathrm{~cm}$, scanner: Camag scanner III, detection: Deuterium lamp and mercury lamp, data system: WinCATS software.

\section{OBSERVATIONS AND RESULTS}

\section{Pharmacognostic Study}

Microscopic powder of Manjisthadi kwatha was found various characters according to contain which are depicted in [Table 3 and Figure 1].
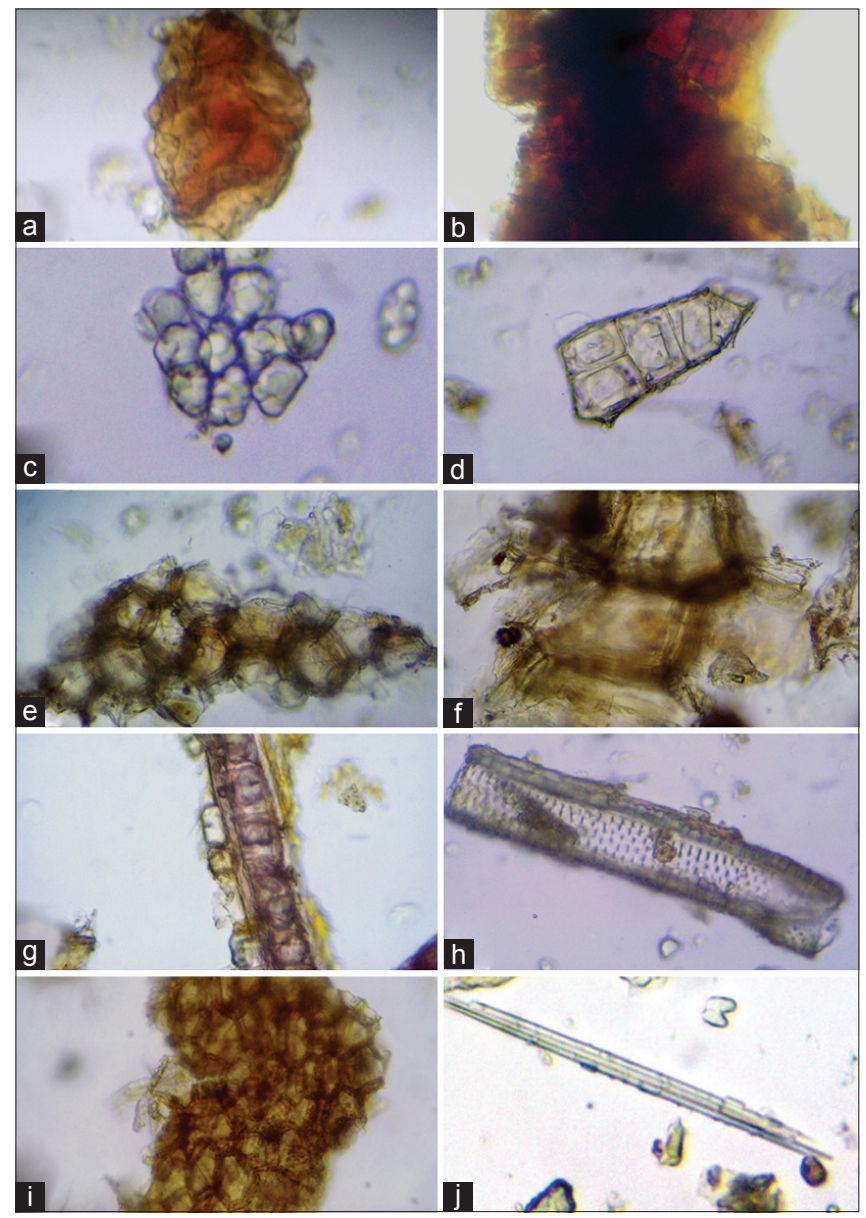

Figure 1: Microscopic characters of Manjisthadi kwatha. (a) Coloring matter of Manjistha (b) dark brown contains of nimb (c) egg-shaped grain of guduchi (d) collenchyma of guduchi (e) cork in surface view of nimba (f) cork cells of manjisthadi (g) crystal fibrous of daruharidra (h) border pitted vessels of manjistha (i) cork cells of guduchi (j) acicular crystal of manjisthadi
Table 3: Microscopic characters of Manjisthadi

\section{Kwatha}

\begin{tabular}{|c|c|}
\hline $\begin{array}{l}\text { Name of } \\
\text { drug }\end{array}$ & Characters found \\
\hline Manjistha & $\begin{array}{l}\text { Border pitted vessels, coloring matters, } \\
\text { acicular crystal }\end{array}$ \\
\hline Nimba & Cork in surface view, dark brown contains \\
\hline Vacha & Starch gain, fibrous of Vacha \\
\hline Katuki & Scalariform vessels, rhomboid crystal \\
\hline Guduchi & $\begin{array}{l}\text { Collenchyma cells, egg-shaped grain, } \\
\text { border pitted vessels }\end{array}$ \\
\hline Daruharidra & $\begin{array}{l}\text { Prismatic crystal, fragment of pitted } \\
\text { vessels, crystal fibrous }\end{array}$ \\
\hline Amalaki & Silica deposition \\
\hline Haritaki & Epicarp, scleroid, stone cells \\
\hline Bibhitaki & Scleroids, trichomes \\
\hline
\end{tabular}
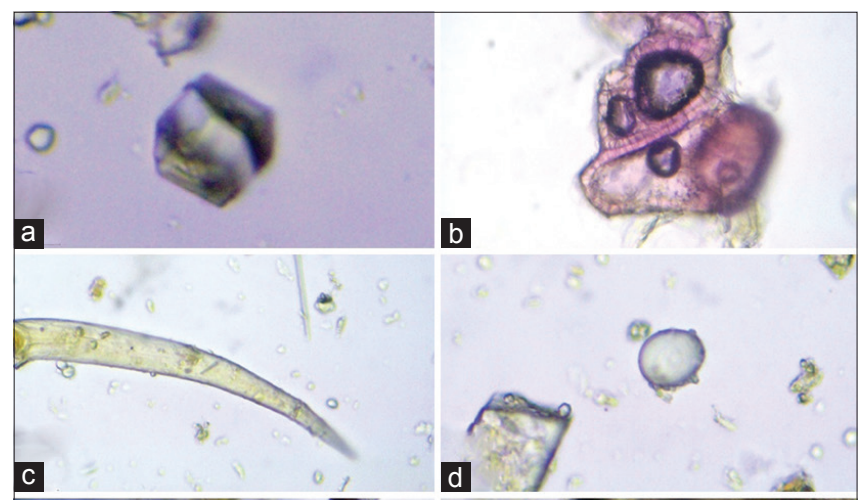

c

a
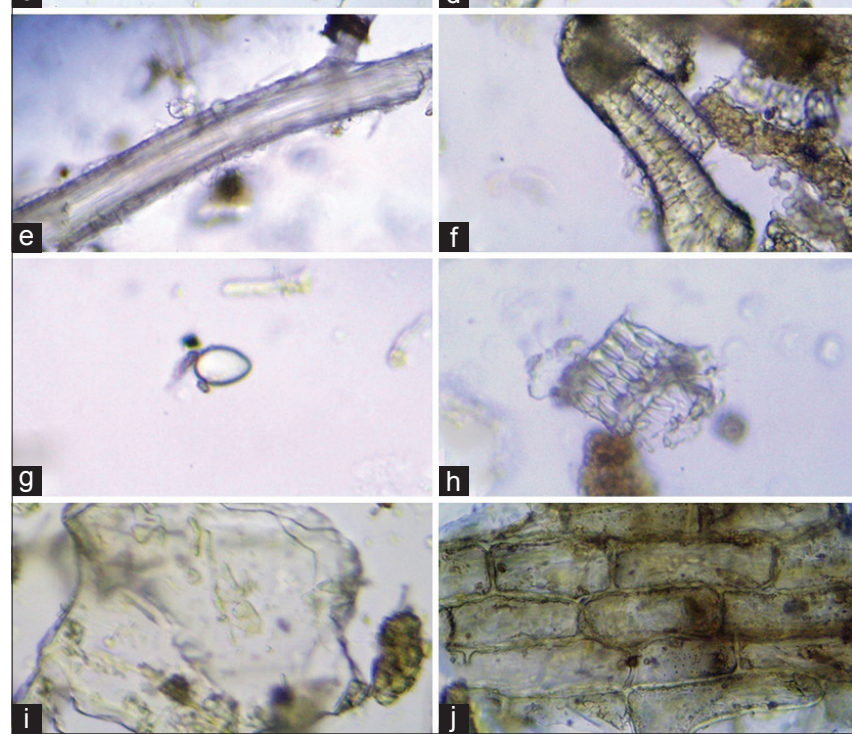

Figure 2: Microscopic characters of Manjisthadi kwatha. (a) Rhomboidal crystal of katuki, (b) stone cells of haritaki, (c) trichome of bibhitaki, (d) oil globules of vacha, (e) silica deposition of amalaki, (f) scleroid of bibhitaki, (g) starch grain of vacha, (h) fragment of pitted vessels of daruharidra, (i) silica deposition of amalaki, (j) epicap cells of amalaki 


\section{Analytical Study}

Results of the analytical study of Manjisthadi kwatha powder are as follows.

\section{Physicochemical Constants}

The results are depicted in Table 4.

\begin{tabular}{|c|c|}
\hline Parameters & Result \\
\hline Loss on drying & $9.025 \% \mathrm{w} / \mathrm{w}$ \\
\hline Ash value & $5.974 \%$ \\
\hline Water soluble extract & $51.568 \% \mathrm{w} / \mathrm{w}$ \\
\hline Alcohol soluble extract & $56.397 \% \mathrm{w} / \mathrm{w}$ \\
\hline $\mathrm{pH}$ & 6.5 \\
\hline
\end{tabular}

\section{HPTLC}

In HPTLC, in short UV-254 nm, maximum 8 spots were observed in Manjisthadi kwatha. Similarly, in long UV-366 nm, maximum 9 spots were observed [Table 5 and Figure 4].

\begin{tabular}{lc}
$\begin{array}{l}\text { Table 5: Chromatographic results of Manjisthadi kwatha } \\
\text { Conditions }\end{array}$ & Rf values (8 spots each) \\
\hline Short ultra violet $(254 \mathrm{~nm})$ & $0.01,0.13,0.26,0.39,0.57$, \\
& $0.64,0.80,0.91$ \\
Long ultra violet $(366 \mathrm{~nm})$ & $0.03,0.19,0.28,0.48,0.56$, \\
& $0.62,0.65,0.85,0.93$
\end{tabular}

Nature of adsorbed components, if with different polarity, formerly total number of components and respective

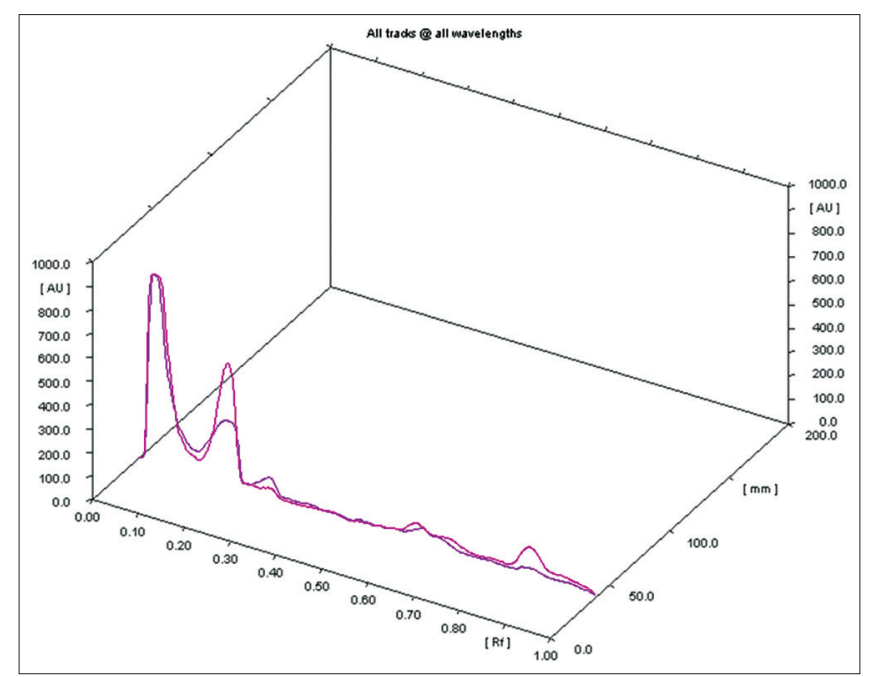

Figure 3: High performance thin layer chromatography three-dimensional evaluation of Manjisthadi kwatha
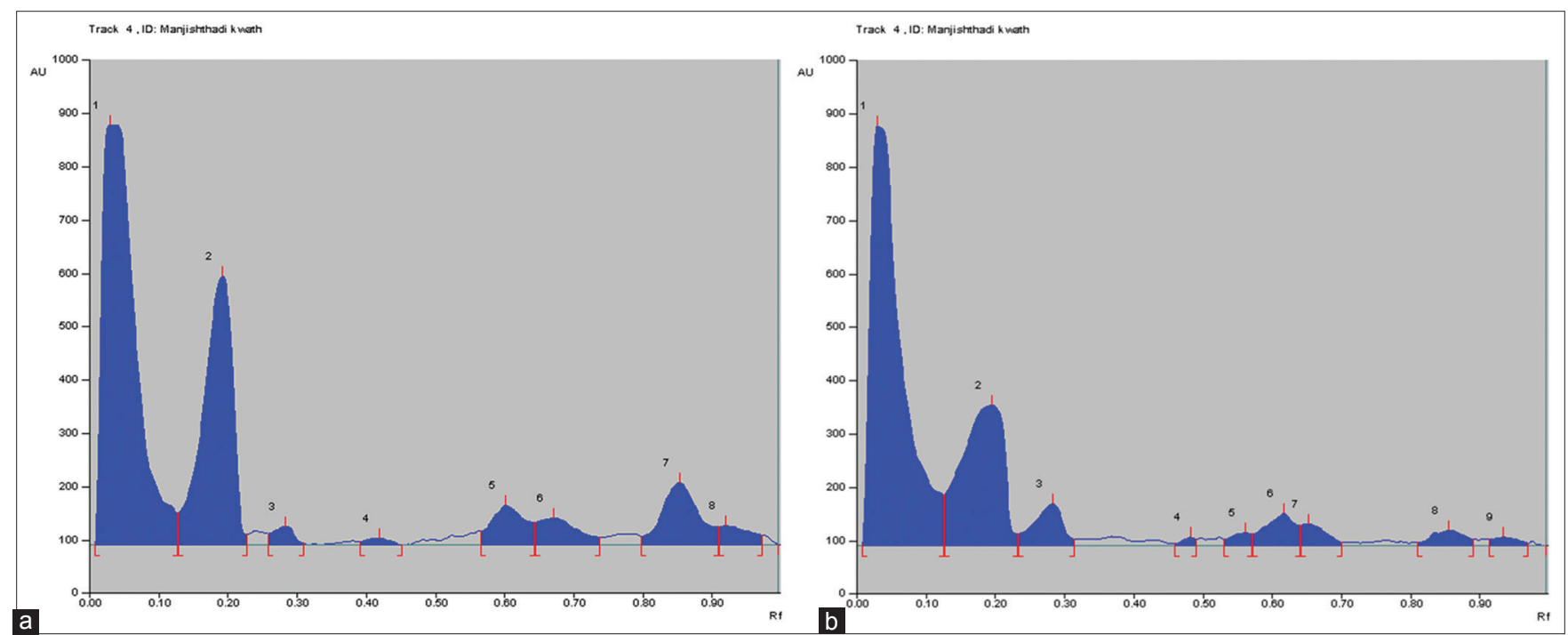

Figure 4: Chromatographic results of Manjisthadi kwatha. (a) On performing high performance thin layer chromatography, the chromatogram of Manjisthadi kwath showed 8 spots at corresponding Rf values $0.01,0.13,0.26,0.39,0.57,0.64,0.80,0.91$. In short wave UV $254 \mathrm{~nm}$, (b) 9 spots corresponding Rf values 0.03,0.19, 0.28, 0.48, 0.56, 0.62, 0.65, 0.85, 0.93. Obtained in long wave UV $364 \mathrm{~nm}$ 
reference values also differs. In short, nature of different matrix modulates both the studied parameters.

\section{DISCUSSION AND CONCLUSION}

Results obtained in physicochemical parameters of Manjisthadi kwatha are within limit mentioned by Ayurvedic pharmacopoeia of India. HPTLC profile of Manjisthadi $k w a t h a$ showed similar in number of spots. This profile can be used for the identification of the medicinally important formulation of Manjisthadi kwatha. This work can be considered as the first step toward identifying the followed methods through HPTLC analysis. This is a preliminary analysis and meticulous nature along with the depiction is to be carried-out.

\section{REFERENCES}

1. Acharya Sharangdhara, Sharngadhara Samhita, Madhyam Khanda 2, Jivanprada Hindi commentary, Editing by Shailaja Srivastava, Chaukhambha orientalia, Varanasi, 2011. p. 137-42.

2. Tripathi YB, Singh VP, Sharma GM, Sinha RK, Singh D. $\mathrm{X}$-ray diffraction and microscopic analysis of Tamra Bhasma: An Ayurvedic metallic preparation. Indian J Tradit Knowl 2003;2:107-17.

3. Shailajan S, Menon S, Singh A. Quantitative analysis of piperine from Ayurvedic polyherbal formulations using reverse phase high performance liquid chromatography. Int J Pharm Bio Sci 2009;1:1-10.

4. Siddiqui A, Hakim MA. Format for the pharmacopoeial analytical standards of compound formulation, workshop on standardization of Unani drugs, (appendix) New Delhi: Central Council for Research in Unani Medicine; 1995.

5. Mukherjee PK. Quality Control of Herbal Drugs. $2^{\text {nd }}$ ed. New Delhi: Business Horizons; 2007. p. 164-5.

6. Anonymous. Indian Pharmacopeia, Appendix 8 (8.6). Vol. II. New Delhi: Government of India, Ministry of Health and Family Welfare, The Controller of Publication; 1996. p. A89.

7. Anonymous. Indian Pharmacopeia, Appendix 8 (8.11). Vol. II. New Delhi: Government of India, Ministry of Health and Family Welfare, The Controller of Publication; 1996. p. A95.

8. Anonymous. The Ayurvedic Pharmacopoeia of India, Part 1, Appendix 2 (2.2.3). $1^{\text {st }}$ ed., Vol. VI. New Delhi: Government of India, Ministry of Health and Family Welfare; 2008. p. 242.

9. Anonymous. The Ayurvedic Pharmacopoeia of India, Part 1, Appendix 2 (2.2.8). $1^{\text {st }}$ ed., Vol. VI. New Delhi: Government of India: Ministry of Health and Family Welfare; 2008. p. 243.

10. Anonymous. The Ayurvedic Pharmacopoeia of India, Part 1, Appendix2 (2.2.7). $1^{\text {st }}$ ed., Vol. VI. New Delhi: Government of India: Ministry of Health and Family Welfare; 2008. p. 243.

11. Shukla VJ, Bhatt UB. Methods of Qualitative Testing of some Ayurvedic Formulations. Jamnagar: Gujarat Ayurvedic University; 2001.

12. Anonymous. Ayurvedic Pharmacopoeia of India, Part2, Appendices. $1^{\text {st }}$ ed., Vol-2. New Delhi: Government of India, Ministry of Health of Family Welfare; 2008. p. 165-7.

Source of Support: Nil. Conflict of Interest: None declared. 